\title{
Jenis Pelarut Metanol Dan N-Heksana Terhadap Aktivitas Antioksidan Ekstrak Rumput Laut Gelidium sp. Dari Pantai Drini Gunungkidul - Yogyakarta
}

\author{
Wahyu Bagio Leksono*, Rini Pramesti, Gunawan Widi Santosa dan \\ Wilis Ari Setyati
}

\author{
Departemen IImu Kelautan, Fakultas Perikanan dan Ilmu Kelautan, Universitas Diponegoro \\ Jl. Prof. Soedarto, SH. Tembalang, Semarang 50275 \\ Email : wbagio14@gmail.com
}

\begin{abstract}
Type of Solvent Methanol And N-Hexane Against Antioxidant Activity Seaweed Extract Gelidium sp. From Drini Beach Gunungkidul - Yogyakarta
\end{abstract}

Gelidium sp. the one of red seaweed which has potential as natural antioxidant. The researh was to know the activity of methanol extract, n-hexane Gelidium sp., and determined total phenolic compound of pigments (chlorophyll a and carotenoid). Decriptive explorative method was used in this research and it was taken from Drini Beach, Gunungkidul, Yogyakarta. Maseration to this sample was done by methanol as solvent, evaporated by rotary evaporator and partitied by n-hexane solvent with separatory funnel. Antioxidant activity was determined by transfer electron method using DPPH (1,1-diphenyl-2-picrylhidrazyl) as free radicals. Total phenolic compound being tested using Folin-Ciocalteu solution with gallic acid as standard and measured at a wavelength of $725 \mathrm{~nm}$, while the chlorophylls were spectrophotometry method and measured at a wavelength of $663 \mathrm{~nm}$ and $646 \mathrm{~nm}$ as well as carotenoids were measured at a wavelength of $470 \mathrm{~nm}$. The results showed that IC 50 value of methanol extract was $340,10 \mathrm{ppm}$ and $\mathrm{n}$-hexane was $66,25 \mathrm{ppm}$. IC 50 value of methanol extract was categorized as very weak in antioxidant activity, while n-heksan extract was categorized as strong. Total phenolic content in each extract were 46,55 and 135,62 (mg GAE/g extract), chlorophyll a 8,47 and 10,88 (mg/g extract sample) and carotenoids 50,38 and $84,27(\mu \mathrm{mol} / \mathrm{g}$ extract sample).

Keywords: Gelidium sp., Antioxidant, DPPH

\begin{abstract}
Abstrak
Gelidium sp. merupakan salah satu rumput laut merah yang berpotensi sebagai sumber antioksidan alami. Penelitian ini bertujuan untuk mengetahui aktivitas antioksidan ekstrak metanol dan n-heksan Gelidium sp. (segar), menentukan kadar total fenolat dan pigmen (klorofil a dan karotenoid). Metode deskriptif eksploratif digunakan dalam penelitian ini dan diperoleh diambil dari Pantai Drini, Gunungkidul, Yogyakarta dibersihkan dengan air tawar, dimaserasi dengan pelarut metanol, diuapkan dengan rotary evaporator dan dipartisi dengan pelarut n-heksan menggunakan corong pemisah (separatory funnel). Aktivitas antioksidan ditentukan dengan metode transfer elektron menggunakan DPPH (1,1-diphenyl-2-picrylhidrazyl) sebagai radikal bebas. Kadar total fenolat diuji dengan metode Folin-Ciocalteu dengan asam galat sebagai larutan standar dan diukur pada panjang gelombang $725 \mathrm{~nm}$. Kadar klorofil a diukur dengan metode spektrofotometri pada panjang gelombang $663 \mathrm{~nm}$ dan $646 \mathrm{~nm}$ sedangkan kadar karotenoid diukur pada panjang gelombang $470 \mathrm{~nm}$. Hasil penelitian menunjukkan nilai IC 50 ekstrak metanol sebesar 340,10 ppm dan ekstrak n-heksan 66,25 ppm. Nilai IC 50 ekstrak metanol termasuk kategori aktivitas antioksidan sangat lemah sedangkan n-heksana termasuk kategori kuat. Kadar total fenolat pada masing-masing ekstrak 46,55 dan 135,62 (mg GAE/g ekstrak), kadar klorofil a sebesar 8,47 dan 10,88 (mg/g sampel) dan kadar karotenoid sebesar 50,38 dan 84,27 ( $\mu \mathrm{mol} / \mathrm{g} \mathrm{sampel).}$
\end{abstract}

Kata kunci: Gelidium sp., Antioksidan, DPPH 


\section{PENDAHULUAN}

Gelidium dapat dimanfaatkan sebagai bahan baku pembuatan agar-agar dan dibidang farmasi sebagai bahan dasar antioksidan dan antibakteri karena mengandung senyawa katekin (Kumar et al., 2008). Salah satu pigmen dominan rumput laut merah adalah fikoeritrin yang berpotensi sebagai antioksidan. Antioksidan yang umum digunakan adalah antioksidan sintetik, seperti butylated hydroxyanisol (BHA), butylated hydroxytolvene (BHT), tert- butylhydroquinone (TBHQ) dan propyl gallate (PG). Antioksidan sintetik bersifat karsinogenik dan dapat menimbulkan kerusakan hati, sehingga permintaan terhadap antioksidan alami terus meningkat. Salah satu alternatif permintaan antioksidan alami berasal dari rumput laut (Nawali et al, 2013).

Penelitian mengenai Gelidium sp. dapat digunakan sebagai penghasil bioetanol (Kawaroe et al., 2014), sebagai agen anti-inflamasi dan antimikroba (Oumaskour et al., 2013). Penelitian tentang uji aktivitas antioksidan Gelidium sp. telah dilakukan antara lain menggunakan jenis $G$. microdon (Paiva et al., 2012) dan G. sesquipedale ( Metidji et al., 2015). Informasi mengenai aktivitas antioksidan Gelidium sp. di Indonesia umumnya dan di Pantai Drini khususnya diduga belum ada sehingga penelitian ini perlu dilakukan.

Hasil penelitian (Ku et al., 2008) Gelidium sp. mengandung senyawa katekin yaitu antioksidan yang kuat, lebih kuat daripada vitamin E, C, dan betakaroten. Jenis katekin yaitu epigallocatechin-gallate (EGCG), epigallocatechin (EGC), epicatechin-gallate (ECG), gallocatechin, dan catechin (Anjarsari, 2016). Katekin merupakan suatu senyawa polifenol yang berpotensi sebagai antioksidan dan antibakteri (Miller, 1996). Katekin bersifat asam lemah, sukar larut dalam air, dan sangat tidak stabil di udara terbuka. Bersifat mudah teroksidasi pada $\mathrm{pH}$ mendekati netral (pH 6,9) dan lebih stabil pada $\mathrm{pH}$ lebih rendah $(2,8$ dan 6,9$)$. Katekin mudah terurai oleh cahaya. Lim et al, (2010) senyawa katekin dapat menghambat pertumbuhan Staphylococcus aureus, Salmonella enteritidis, dan Escherichia coli. Jenis katekin yang memiliki aktivitas antibakteri terkuat adalah epigallocatechin (EGC). Ekstraksi dengan pelarut didasarkan pada sifat kepolaran zat dalam pelarut saat ekstraksi. Senyawa polar hanya akan larut pada pelarut polar seperti etanol, metanol, butanol dan air. Senyawa non-polar hanya dapat larut pada pelarut non-polar, seperti eter, kloroform dan n-heksana.

Radikal bebas adalah atom, molekul atau senyawa yang dapat berdiri sendiri yang mempunyai elektron tidak berpasangan, sehingga bersifat sangat reaktif dan tidak stabil. Elektron yang tidak berpasangan selalu berusaha untuk mencari pasangan baru, sehingga mudah bereaksi dengan zat lain (protein, lemak maupun DNA) dalam tubuh. (Winarti,2010),

Radikal bebas di dalam tubuh merupakan bahan yang sangat berbahaya. Bahan radikal bebas tersebut sebenarnya merupakan senyawa atau molekul yang mengandung satu atau lebih elektron yang tidak berpasangan pada bagian orbital luarnya. Adanya elektron yang tidak berpasangan yang mengakibatkan senyawa tersebut sangat reaktif untuk mencari pasangannya. Caranya dengan mengikat atau menyerang elektron molekul yang berada disekitarnya. Yang diikat radikal bebas pada umumnya adalah molekul besar seperti lipid, protein, maupun DNA (pembawa sifat). Apabila hal tersebut terjadi, maka akan mengakibatkan kerusakan sel atau pertumbuhan sel yang tidak bisa dikendalikan .

Radikal bebas yang bereaksi dengan komponen biologis akan menghasilkan senyawa teroksidasi yang dapat digunakan sebagai penanda kerusakan oksidatif. Komponen endogen yang dapat diserang oleh radikal bebas adalah lipid, protein dan DNA. Radikal bebas memiliki reaktivitas yang sangat tinggi. Hal ini ditunjukkan karena sifatnya yang menarik dalam menyerang elektron disekelilingnya. Radikal bebas dapat mengubah suatu molekul menjadi suatu radikal. Nilai $\mathrm{IC}_{50}$ (Inhibitor Concentration) merupakan konsentrasi larutan substrat atau sampel yang mampu mereduksi aktivitas 
DPPH sebesar $50 \%$. Semakin kecil nilai $I_{50}$ berarti semakin tinggi aktivitas antioksidan. Secara spesifik suatu senyawa dikatakan sebagai antioksidan sangat kuat jika nilai $\mathrm{IC}_{50}$ kurang dari $50 \mathrm{ppm}\left(\mathrm{IC}_{50}<50 \mathrm{ppm}\right)$, kuat (50 $\left.\mathrm{ppm}<\mathrm{IC}_{50}<100 \mathrm{ppm}\right)$, sedang (100 ppm < $\mathrm{IC}_{50}<150 \mathrm{ppm}$ ), lemah (150 ppm $<\mathrm{IC}_{50}<200$ ppm), dan sangat lemah (IC 50200 ppm). Strukur DPPH radikal bebas dan DPPH yang telah bereaksi dengan antioksidan disajikan pada Gambar 1.

\section{MATERI DAN METODE}

Materi yang digunakan dalam penelitian ini adalah rumput laut jenis Gelidium sp. segar yang diperoleh dari pantai Drini Kabupaten Gunungkidul. Ekstraksi dilakukan (Santoso et al., 2012) dengan modifikasi pada perbandingan volume sampel dan pelarut. Sampel ditimbang sebanyak 125 gram dan dipotong kecil 0,5 $\mathrm{cm}$ lalu dimaserasi di dalam metanol (teknis) sebanyak $500 \mathrm{~mL}$ selama $2 \times 24$ jam pada suhu $\pm 28^{\circ} \mathrm{C}$. Larutan extrak diperoleh melalui penyaringan menggunakan kertas Whatman 41 kemudian dievaporasi menggunakan vaccum rotary evaporator pada suhu $40{ }^{\circ} \mathrm{C}$ hingga volume tersisa $\pm 125 \mathrm{~mL}$. Larutan hasil evaporasi selanjutnya difraksinasi dengan pelarut $\mathrm{n}$-heksan menggunakan corong pemisah dengan perbandingan 1:3 hingga terlihat dua lapisan. Lapisan bawah merupakan metanol dan lapisan atas $\mathrm{n}$ heksan. Hasil filtrat masing-masing pelarut dievaporasi untuk mendapatkan ekstrak berupa pasta. Rendeman ekstrak dihitung menggunakan rumus :

$$
\begin{gathered}
\% \text { Rendemen }= \\
\frac{\text { Jumlah berat ekstrak berupa pasta }(g)}{\text { Jumlah berat awal }(g)} \times 100 \%
\end{gathered}
$$

Keterangan :

Berat ekstrak $=$

(Berat vial + ekstrak) - berat vial kosong (g)

Uji kandungan total fenol dilakukan untuk mengetahui jumlah total senyawa fenolat yang terdapat pada sampel. Pengujian kadar total fenol (Yangthong et al.,2009) yaitu menggunakan asam galat sebagai kurva standar untuk menentukan kadar fenol ekstrak. Asam galat digunakan sebagai standar dengan konsentrasi $0,10,20$, 30 , dan $40 \mathrm{mg} / \mathrm{L}$. Ekstrak sebanyak $5 \mathrm{mg}$ dilarutkan dalam $2 \mathrm{~mL}$ etanol p.a lalu ditambahkan $5 \mathrm{~mL}$ aquades dan $0,5 \mathrm{~mL}$ reagen Folin-Ciocalteau $50 \%$. Larutan didiamkan selama 5 menit kemudian ditambahkan $1 \mathrm{~mL} \mathrm{Na} \mathrm{CO}_{3} 5 \%(\mathrm{~b} / \mathrm{v})$. Larutan diaduk supaya homogen lalu diinkubasi dalam kondisi gelap selama satu jam. Absorbansi diukur menggunakan spektrofotometer UV-Vis pada panjang gelombang $725 \mathrm{~nm}$. Nilai total fenol ekstrak dinyatakan dalam "mg Galic Acid Equivalent (GAE)/g ekstrak

$$
\text { Total fenol }=\frac{(a \times V) / 1000}{G}
$$

Keterangan :

a =konsentrasi asam galat dalam sampel uji (mg/Lt)

$\mathrm{V} \quad=$ volume total larutan uji $(\mathrm{mL})$

$\mathrm{G} \quad=$ massa ekstrak yang digunakan (g)

1000 =faktor konversi terhadap volume total larutan $(\mathrm{mL})$

Pengukuran Klorofil a dan karotenoid (Lichtenthaler, 1987). Ekstrak dari tiap pelarut ditimbang sebanyak $5 \mathrm{mg}$, kemudian dilarutkan dengan konsentrasi $5 \mathrm{mg}$ ekstrak $/ 5 \mathrm{~mL}$ aseton $80 \%$. Masing-masing konsentrasi diukur absorbansinya pada panjang gelombang $646 \mathrm{~nm}, 663 \mathrm{~nm}$, dan $470 \mathrm{~nm}$. Kadar klorofil dan karotenoid dihitung berdasarkan rumus:

$$
\text { Klorofil a mg/g sampel }(\mathrm{Ca})=
$$$$
12,21 \times A_{663}-2,81 \times A_{646}
$$

Karotenoid $\mu \mathrm{mol} / \mathrm{g}$ sampel $(\mathrm{Cx}+\mathrm{C})=$ $(A 470+0,114 x A 663-0,638 x$ A646)xVx1000

$$
112,5 \times 0,1 \times 10
$$

Keterangan:

$$
\begin{array}{rlrl}
\mathrm{A}_{663}= & \text { Absorbansi } \quad \text { pada } & \text { panjang } \\
& \text { gelombang } 663 \mathrm{~nm} & & \\
\mathrm{~A}_{646}= & \text { Absorbansi } \quad \text { pada } & \text { panjang } \\
& \text { gelombang } 646 \mathrm{~nm} & \\
\mathrm{~A}_{470}= & \text { Absorbansi } \quad \text { pada } & \text { panjang } \\
& \text { gelombang } 470 \mathrm{~nm} & \\
\mathrm{~V}= & \text { Volume ekstrak } &
\end{array}
$$

Pengujian aktivitas antioksidan dengan prosedur menurut Miliauskes et al. (2004) $3 \mathrm{~mL}$ larutan DPPH 0,15 mM ditambahkan kedalam $1,5 \mathrm{~mL}$ ekstrak pada konsentrasi stok 50, 100 , 
150, 200, dan 250 ppm diinkubasi pada suhu $37{ }^{\circ} \mathrm{C}$ selama 30 menit, kemudian diukur absorbansi menggunakan spektrofotometer UV-Visible pada panjang gelombang $517 \mathrm{~nm}$. Aktivitas antioksidan dihitung menggunakan rumus:

Penghambat Radikal Bebas $(\%)=\frac{(\mathrm{A}-\mathrm{B})}{\mathrm{A}} \times 100$

Keterangan :

$\mathrm{A}=$ Absorbansi kontrol negatif (larutan DPPH tanpa ekstrak)

$B=$ Absorbansi (sampel uji)

Nilai penghambat radikal bebas DPPH (\%) digunakan untuk menentukan nilai $\mathrm{IC}_{50}$. Nilai $I_{50}$ merupakan besarnya konsentrasi larutan uji untuk meredam $50 \%$ aktivitas radikal bebas. $\mathrm{IC}_{50}$ dihitung dari persentasi penghambat radikal bebas (\%) dengan menggunakan persamaan yang diperoleh dari kurva regresi linier.

\section{HASIL DAN PEMBAHASAN}

Ciri morfologi rumput laut Gelidium sp. yang diperoleh yaitu thallus panjang $7-8 \mathrm{~cm}$, berwarna coklat kemerahan dan berbentuk silindris dengan percabangan tidak teratur yang keluar dari stolon. Thallus mempunyai ranting pendek (ramuli) yang tumbuh berderet bersebelahan pada percabangan. Karakteristik pada Gelidium sp. umumnya ada ramuli terletak berderet pada satu sisi. Hasil ekstraksi Gelidium sp. dengan berat segar 125 gram dengan menggunakan 2 pelarut yaitu metanol dan n-heksan ditampilkan pada Tabel 1.

Aktivitas antioksidan dihitung dengan nilai $\mathrm{IC}_{50}$ yang diperoleh dari persamaan regresi linier konsentrasi ekstrak terhadap nilai inhibisi DPPH. Berdasarkan persamaan ini diketahui nilai $\mathrm{R}^{2}$ ekstrak metanol sebesar 0,5329 dan $n$-heksana 0,8529. Nilai $R^{2}$ menunjukkan korelasi antara persen (\%) inhibisi dan konsentrasi ekstrak, dari hasil ini memberikan korelasi positif. Nilai aktivitas antioksidan dari ekstrak $n$-heksana sebesar 94,59 ppm dan metanol 213,28 ppm. Nilai ini diduga dipengaruhi komponen, seperti fenol, klorofil a, dan karotenoid. Tiga komponen tersebut mempunyai hasil yang sinergis, yaitu nilai dari ekstrak n-heksana lebih besar dibandingkan dengan ekstrak metanol. Konsentrasi ekstrak yang digunakan yaitu 50 , 100, 150, 200 dan 250 ppm. Kontrol positif menggunakan Vitamin $C$ dengan konsentrasi $2,3,4,5$ dan 6 ppm. Nilai absorbansi DPPH, absorbansi DPPH + ekstrak, inhibisi IC 50 pada Tabel 2.

Tabel 1. Hasil Ekstraksi Gelidium sp.

\begin{tabular}{cccc}
\hline Pelarut & $\begin{array}{c}\text { Berat } \\
\text { Ekstrak (g) }\end{array}$ & Bentuk & Warna \\
\hline Metanol & 0,214 & pasta & hijau tua \\
n-heksan & 0,850 & pasta & hijau tua \\
\hline
\end{tabular}

Nilai $I_{50}$ dihitung menggunakan persamaan regresi linier yang diperoleh dari hubungan konsentrasi ekstrak terhadap persen inhibisi DPPH. Hasil dari persamaan regresi linier $y=0,1436 x+19,372$ untuk ekstrak metanol dan $y=0,370 x+14,951$ untuk ekstrak $\mathrm{n}$-heksana. Berdasarkan hasil perhitungan dari hubungan konsentrasi ekstrak vitamin $C$ dengan persen inhibisi DPPH diperoleh persamaan regresi linier $y=22,401 x$ 16,899 Hasil penentuan aktivitas antioksidan, total fenol, klorofil a, dan karotenoid ekstrak Gelidium sp. ditampilkan pada Tabel 2.

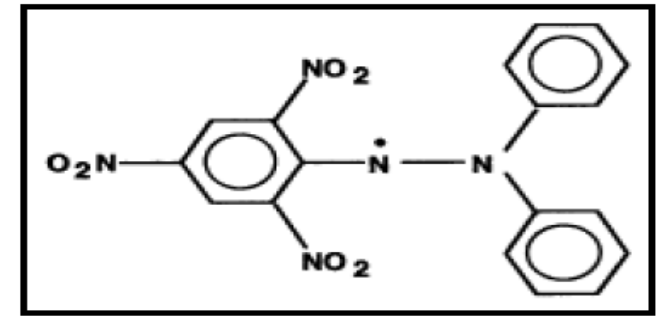

a. 1,1-diphenyl-2-picrylhydrazil

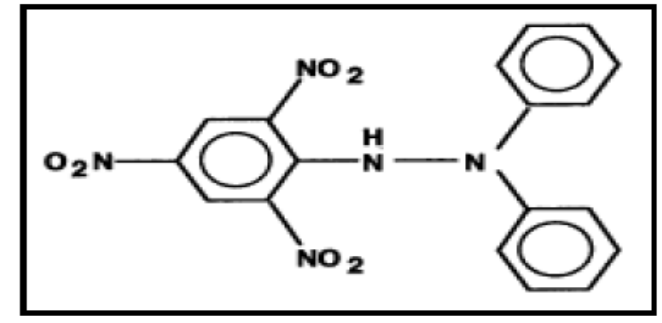

b. 1,1-diphenyl-2-picrylhydrazin

Gambar 1. Struktur DPPH (a) Radikal Bebas dan (b) Radikal Bebas yang Telah Bereaksi dengan dengan Antioksidan (Molyneux, 2004). 
Ekstrak rumput laut Gelidium sp. memiliki rendemen ekstrak metanol sebesar $0,171 \%$ dan $n$-heksan sebesar $0,680 \%$. Hal ini diduga Gelidium sp. memiliki senyawa bioaktif yang bersifat non-polar lebih banyak daripada senyawa polar. Setiap pelarut memiliki karakter berbeda dalam mengambil senyawa bioaktif suatu sampel yang

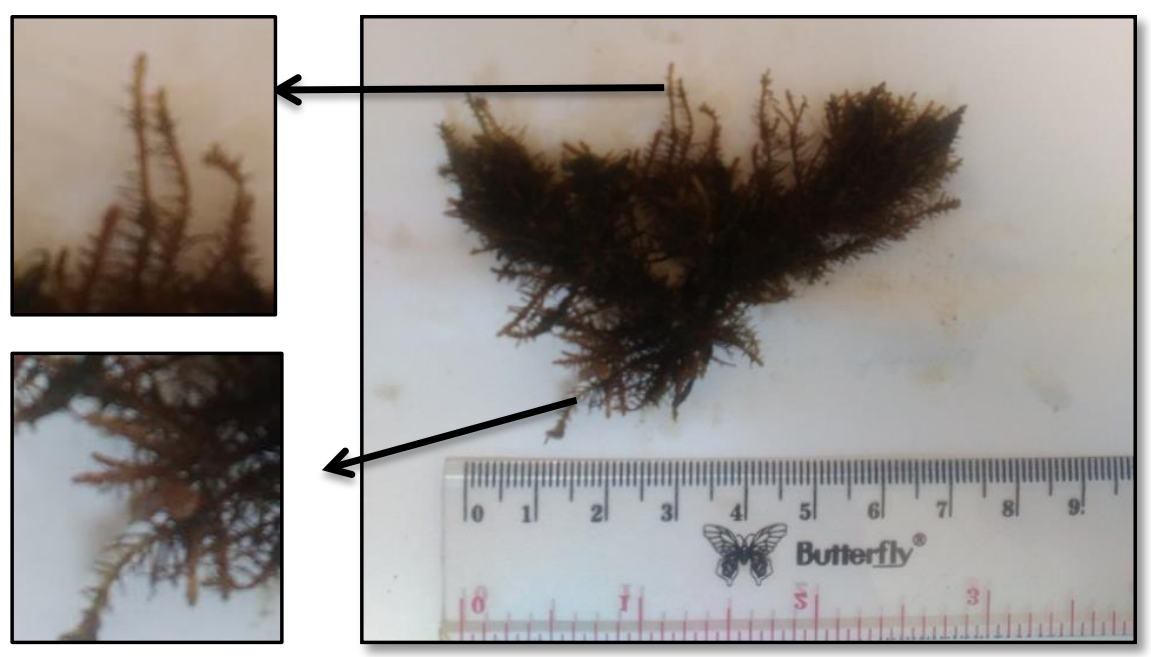

Gambar 2. Rumput Laut Gelidium sp. dari Pantai Drini Gunung Kidul

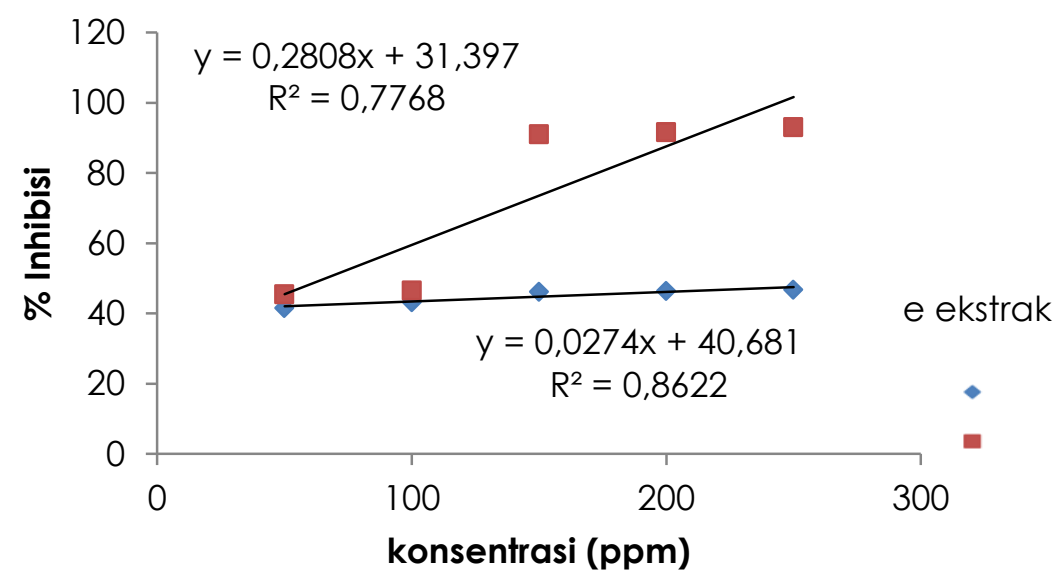

Gambar 3. Inhibisi Ekstrak Gelidium sp.

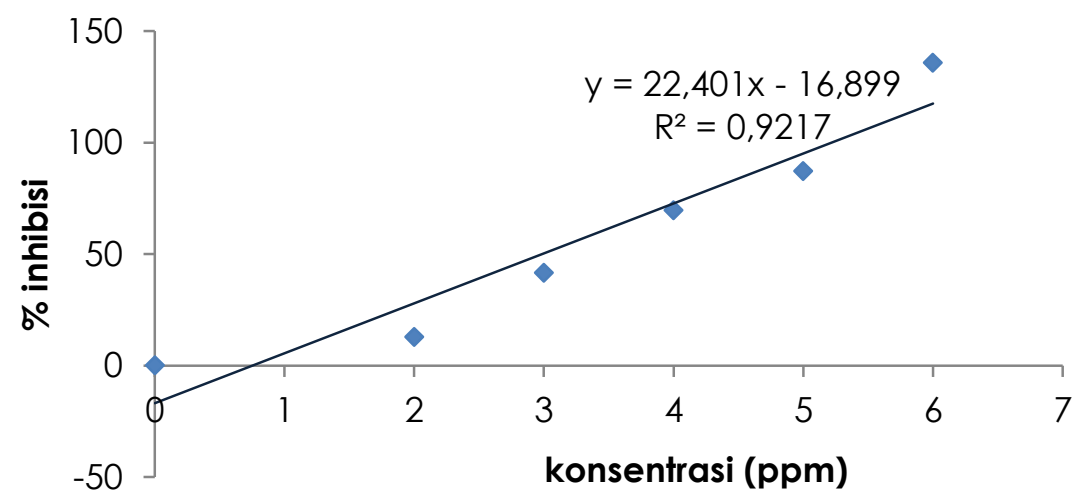

Gambar 4. Inhibisi Vitamin C 
Tabel 2. Nilai $I_{50}$, Total Fenolik, Klorofil a, dan Karotenoid Gelidium sp.

\begin{tabular}{lrc}
\hline \multicolumn{1}{c}{ Parameter } & \multicolumn{2}{c}{ Jenis ekstrak } \\
\cline { 2 - 3 } Nilai IC 50 (ppm) & metanol & n-heksan \\
Total fenolik ( mg GEA/g ekstrak) & 340,10 & 66,25 \\
Klorofil a (mg/g sampel) & 46,55 & 135,62 \\
Karotenoid ( $\mu$ mol/g sampel) & 8,47 & 10,88 \\
\hline
\end{tabular}

berbeda kepolarannya. Pelarut metanol dan n-heksan digunakan dalam ekstraksi untuk mendapatkan senyawa berdasarkan tingkat kepolarannya (polar dan non-polar). Sarastani et al. (2002) ekstraksi menggunakan pelarut dengan polaritas berbeda dapat menghasilkan ekstrak dengan polaritas yang berbeda pula sesuai dengan sifat kepolaran masing-masing ekstrak.

Hasil ekstraksi pada ekstrak metanol dan n-heksan menunjukkan warna hijau. Hal ini menunjukkan sampel banyak mengandung klorofil. Rumput laut merah memiliki kandungan pigmen berupa klorofil a, klrofil d, fikobiliprotein (fikoeritirin dan fikosianin), karotenoid dan xantofil (Van et al., 1995)

Ekstrak sampel menghasilkan senyawa bioaktif berupa klorofil a pada ekstrak nheksan sebesar 10,88 mg/g sampel, lebih tinggi dibanding ekstrak metanol sebesar $8,47 \mathrm{mg} / \mathrm{g}$ sampel. Klorofil termasuk jenis pigmen non-polar sehingga larut dalam pelarut non-polar (Richmond 2008). Kadar klrofil a pada rumput laut merah merupakan yang paling kecil bila dibanding dengan rumput laut hijau dan coklat (Fleurence \& Levine, 2016)

Kadar karotenoid pada pelarut $\mathrm{n}$ heksan 84,27 $\mu \mathrm{mol} / \mathrm{g}$ sampel, lebih tinggi jika dibandingkan dengan pelarut metanol 50,38 $\mu \mathrm{mol} / \mathrm{g}$ sampel. Hal ini diduga karotenoid pada sampel termasuk dalam karotenoid non-polar (a-karoten dan $\beta$-karoten). Kandungan karotenoid pada beberapa rumput laut merah beragam dari 0,5-52,5\% berat kering (Esteban et al., 2008). Faktor musim, lokasi geografi tempat tumbuh, jenis spesies, umur panen hingga kondisi lingkunga mempengaruhi ragam kandungan pigmen (Fleurence \& Levine, 2016)
Aktivitas antioksidan pada sampel dinyatakan dalam persen inhibisi terhadap radikal bebas DPPH. Persen inhibisi didapat dari pengurangan nilai absorbansi DPPH dengan absorbansi DPPH ditambah ekstrak. Untuk menginterpretasikan hasil, parameter yang digunakan adalah $\mathrm{IC}_{50}$ yang merupakan konsentrasi suatu sampel dalam meredam $50 \%$ aktivitas radikal bebas.

Hasil perhitungan menunjukkan $\mathrm{IC}_{50}$ ekstrak metanol rumput laut Gelidium sp. sebesar 340,10 ppm dan ekstrak n-heksan sebesar 66,10 ppm. Hasil ini menunjukkan ekstrak n-heksan memiliki efektivitas lebih baik dalam meredam radikal bebas DPPH. Mardawati et al. (2008) dalam penggolongan aktivitas antioksidan dari ekstrak rumput laut Gelidium sp. tergolong kuat pada ekstrak pelarut n-heksan, sedangkan ekstrak pelarut metanol tergolong sangat lemah. Hasil yang berbeda antara ekstrak metanol dan n-heksan ini diduga, karena sampel yang diuji merupakan ekstrak kasar. Ekstrak yang belum murni masih mengandung senyawa-senyawa lain yang berasal dari laut seperti garam, nutrient-nutrien, dan mineral yang dapat menghambat kerja dari senyawa antioksidan. Hal ini didukung oleh penelitian yang dilakukan Wikanta et al. (2005), rendahnya aktivitas antioksidan dapat dikarenakan adanya zat pengotor yang terdapat dalam ekstrak masih tinggi.

Hasil yang diperoleh dari ekstrak nheksan tergolong kuat sedangkan dari ekstrak metanol tergolong rendah, namun jika dibandingkan dengan aktivitas antioksidan rumput laut merah lain seperti pada jenis Halymenia harveyana dan Eucheuma cottonii (Suryaningrum et al., 2006) menghasilkan $I_{50}$ pada ekstrak metanol sebesar 176,5 ppm sedangkan pada ekstrak n-heksan lebih dari 2000 ppm. 
Aktivitas antioksidan ekstrak n-heksan lebih efektif dalam meredam radikal bebas dibanding ekstrak metanol. Hal ini diduga karena nilai senyawa fenol, klorofil a dan karotenoid menunjukkan nilai dengan pelarut $n$-heksan lebih tinggi dibanding metanol. Hal tersebut berpengaruh terhadap aktivitas antioksidan, semakin tinggi kadar senyawa tersebut maka semakin kuat aktivitas antioksidannya (Sanger et al., 2013).

Pengujian total fenol bertujuan menentukan senyawa fenolik yang terkandung di dalam sampel, bila kandungan senyawa fenolik di dalam sampel tinggi maka aktivitas antioksidannya akan tinggi (Gross, 1991). Hasil penelitian menunjukkan hubungan yang positif, karena nilai total fenol ekstrak n-heksan sinergis dengan aktivitas antioksidan ekstrak nheksana Gelidium sp. mengandung katekin yang dapat menjadi bahan dasar sebagai aktivitas antioksidan (Kumar et al., 2008). Katekin merupakan salah satu senyawa hasil turunan fenol. Senyawa fenol yang terdapat pada ekstrak Gelidium sp. tidak dilakukan proses identifikasi sehingga tidak diketahui senyawa fenol apa saja yang terdapat dalam ekstrak.

Klorofil a dan karotenoid berperan sebagai antioksidan. Ditambahkan (Sangi et al, 2008) Triterpenoid merupakan salah satu senyawa yang berpotensi sebagai antioksidan, biasanya larut dalam pelarut non-polar, sedangkan Sheikh et al, (2009) senyawa fenolik terbanyak tidak selalu terdapat dalam pelarut polar, namun tergantung dari struktur senyawa fenoliknya karena pada Turbinaria conoides kadar total fenol ekstrak $n$ - heksana lebih tinggi dibanding ekstrak metanol (Setyati et al, 2017). Damogalad et. al. (2013) menyatakan flavonoid sebagai antioksidan dan klorofil a dapat meredam radikal bebas karena adanya logam Mg yang terkelat dan kerangka porfirin yang dimilikinya. Logam yang terkelat akan membuat radikal bebas cenderung memberikan elektronnya kepada logam Mg, sehingga dapat menetralkan karakter radikal bebas. Logam Mg pada klorofil dapat berpengaruh pada aktivitas antioksidan klorofil jika dalam bentuk terkelat bukan dalam bentuk ionik (Gross, 1991).
Setiap kelas rumput laut memiliki perbedaan rasio akumulasi jenis karotenoid sebagai contoh fukosantin yang merupakan salah satu jenis karotenoid dan memiliki akumulasi yang tinggi pada rumput laut coklat, sedangkan $\beta$-karoten akumulasinya cukup tinggi pada beberapa jenis rumput laut merah (Liu et al., 2009) dan akumulasi karotenoid dalam rumput laut dapat dimanfaatkan sebagai antioksidan. Penghambatan radikal bebas oleh karotenoid dilakukan oleh $\beta$-karoten. Aktivitas antioksidan $\beta$-karoten dapat menunjukkan pro-oksidan secara autokatalitik (Limantara \& Rahayu, 2008).

\section{KESIMPULAN}

Hasil penelitian menunjukkan nilai $\mathrm{IC}_{50}$ ekstrak metanol sebesar 340,10 ppm dan ekstrak n-heksan 66,25 ppm. Nilai IC 50 ekstrak metanol termasuk kategori aktivitas antioksidan sangat lemah sedangkan nheksana termasuk kategori kuat. Kadar total fenolat pada masing-masing ekstrak 46,55 dan 135,62 (mg GAE/g ekstrak), kadar klorofil a sebesar 8,47 dan 10,88 (mg/g ekstrak sampel) dan kadar karotenoid sebesar 50,38 dan 84,27 ( $\mu \mathrm{mol} / \mathrm{g}$ ekstrak sampel).

\section{DAFTAR PUSTAKA}

Anjarsari, I.R.D. 2016. Katekin teh Indonesia: prospek dan manfaatnya. Kultivasi. 15(2):99-106

Damogalad, V., Edy, H.J., \& Supriati, H.S. 2013. Formulasi Krim Tabir Surya Ekstrak Kulit Nanas (Ananas comosus L Merr) Dan Uji In Vitro Nilai Sun Protecting Factor (Spf). Pharmacon. 2(2):12-16.

Esteban, R., Martínez, B., Fernández-Marín, B., Maria Becerril, J., \& García-Plazaola, J.I. 2009. Carotenoid composition in Rhodophyta: insights into xanthophyll regulation in Corallina elongata. Europ. J. Phycol. 44(2):221-230.

Fleurence, J., \& Levine, I. (Eds.). 2016. Seaweed in health and disease prevention. Academic Press.

Gross, J. 1991. Pigments in Vegetable. Chlorophylls and Carotenoids. Van Nostrand Reinhold. New York.

Hoek, C., Mann, D., \& Jahns, H.M. 1995. Algae: an introduction to phycology. Cambridge University Press. 
Ku, K. J., Hong, Y.H., \& Song, K. B. 2008. Mechanical properties of a Gelidium corneum edible film containing catechin and its application in sausages. J. Food Sci. 73(3): C217-21. DOI : 10.1111/j.1750$3841.2008 .00700 . x$

Kawaroe, M., Rusmana, I., \& Nurafni. 2013. Production of Bioethanol from Macroalgae Gelidium sp. Using Agarase Enzymes of Marine Bacteria. Bogor. Institut Pertanian Bogor.

Lim, G.O., Jang, S.A., \& Song, K.B. 2010. Physical and antimicrobial properties of Gelidium corneum/nano-clay composite film containing grapefruit seed extract or thymol. J. Food Eng. 98(4):415-420.

Limantara, L.P \& Rahayu. 2008. Prospek Kesehatan Pigmen Alami. Prosiding Seminar Nasional Sains dan Teknologi Pigmen Alami, Universitas Kristen Satya Wacana, Salatiga, p: 2-42.

Liu, C.L., Huang, Y.S., Hosokawa, M., Miyashita, K., \& Hu, M.L. 2009. Inhibition of proliferation of a hepatoma cell line by fucoxanthin in relation to cell cycle arrest and enhanced gap junctional intercellular communication. Chemicobiological interactions. 182(2-3):165-172.

Metidji, H., Dob, T., Toumi, M., Krimat, S., Ksouri, A., \& Nouasri, A. 2015. In vitro screening of secondary metabolites and evaluationof antioxidant, antimicrobial and cytotoxic properties of Gelidium sesquipedale Thuret et Bornet red seaweed from Algeria.

Miller, N.D.1996. Antioxidant Flavonoid Structure and Clinic Usage. Throne Research. 2:103-111.

Molyneux, P. 2004. The use of the stable free radical diphenylpicrylhydrazyl (DPPH) for estimating antioxidant activity. Songklanakarin J. Sci. Technol, 26(2):211219.

Nawaly, H., Susanto, A.B., \& Uktolseja, J.L. 2013. Senyawa Bioaktif dari Rumput Laut sebagai Antioksidan. Prosiding Seminar Biologi 10(1):9088

Oumaskour, K., Boujaber, N., Etahiri, S. \& Assobhel, O. 2013. Anti-Inflammatory and Antimicrobial Activities of Twenty-Three Marine Algae from the Coast of SidiBouzid (El Jadida-Morocco). Int. J. Pharm. Pharm. Sci, 5:145-149.
Paiva, L.S., Patarra, R.F., Neto, A.I., Lima, E. \& Baptista, J.A. 2012. Antioxidant activity of macroalgae from the Azores. Arquipélago. Life and Marine Sciences, 16.

Richmond, A. (Ed.) 2008. Handbook of microalgal culture: biotechnology and applied phycology. John Wiley \& Sons.

Setyati, W. A., Zainuddin, M., \& Pramesti, R. 2017. Aktivitas Antioksidan Senyawa NonPolar Dan Polar Dari Ekstrak Makroalga Acanthophora muscoides Dari Pantai Krakal Yogyakarta. Jurnal Enggano, 2(1):68-77

Santoso, J., Anwariyah, S., Rumiantin, R.O., Putri, A.P., Ukhty, N., \& Yoshie-Stark, Y. 2012. Phenol content, antioxidant activity and fibers profile of four tropical seagrasses from Indonesia. J. coast. Dev.15(2):189-196.

Sarastani, D., Soekarto, S.T., Muchtadi, T.R., Fardiaz, D., \& Apriyantono, A. 2002. Aktivitas antioksidan ekstrak dan fraksi ekstrak biji atung. J. Teknol. Ind. Pang. 13(2):149-156.

Sanger, G., Widjanark, S.B., Kusnadi, J., \& Berhimpon, S. 2013. Antioxidant Activity of Methanol Extract $f$ Sea Weeds Obtained from North Sulawesi. Food Sci. Quality Manag. 19:2224-6088.

Sangi, M., Runtuwene, M.R., Simbala, H.E., \& Makang, V.M. 2008. Analisis fitokimia tumbuhan obat di Kabupaten Minahasa Utara. Chem. Prog. 1 (1):47-53.

Sheikh, T.Z.B., Yong, C.L., \& Lian, M.S. 2009. In vitro antioxidant activity of the hexane and methanolic extracts of Sargassum baccularia and Cladophora patentiramea. J. App. Sci. 9(13):24902493.

Wikanta, T., Januar, H.D. \& Nursed, M. 2005. Uji Aktivitas Antioksidan, Toksisitas dan Sitoksisitas Ekstrak Alga Merah Rhodymenia palmate. J. Pen. Per. Ind. 11 (4): 41-49

Yangthong, M., Hutadilok-Towatana, N., \& Phromkunthong, W. 2009. Antioxidant activities of four edible seaweeds from the southern coast of Thailand. Plant Foods Human Nutri. 64(3):218-223. 